\title{
Bioassay of selected fungicides for control of chalkbrood in alfalfa leafcutter bees, Megachile rotundata*
}

\author{
MS Goettel **, KW Richards, G Bruce Schaalje
}

Agriculture Canada Research Station, PO Box 3000 Main, Lethbridge, Alberta, Canada T1J 4B1

(Received 17 September 1990; accepted 3 July 1991)

\begin{abstract}
Summary - Bioassays were carried out to determine the effects of 5 selected fungicides on various developmental parameters on the incidence of chalkbrood in Megachile rotundata. The fungicides were bioassayed by incorporation into the natural provisions of leafcutter bees at the egg stage. Half of the fungicide-treated individuals were challenged with $1 \times 10^{6}$ ascospores of Ascosphaera aggregata $24 \mathrm{~h}$ after treatment with fungicide. Addition of spore inoculum increased mortality, but chalkbrood levels remained under $50 \%$. All fungicides tested had no effects on bee mortality of nonchallenged larvae at doses $\leq 100 \mathrm{ppm}$. At $1000 \mathrm{ppm}$, increased mortality occurred in the Ascocidin, Rovral and enilconazole treatments. Treatment with Rovral resulted in earlier mortality and a slightly prolonged developmental time. Ascocidin, Benlate and Rovral reduced levels of chalkbrood but were toxic to larvae. Consequently these compounds had no effect on total mortality. Treatment with DFMO resulted in increased levels of chalkbrood. Mean developmental times for dying larvae measured by the time to defecation were increased with Rovral. Treatment with Ascocidin, Benlate, DFMO and Rovral resulted in heavier sporulating cadavers compared with controls. This increase in weight of cadavers may translate to increased spore loads.
\end{abstract}

Ascosphaera aggregata / Megachile rotundata / chalkbrood / chemical control / fungicide

\section{INTRODUCTION}

The alfalfa leafcutter bee, Megachile rotundata $(F)$, is used extensively in the northwestern United States and western Canada for pollination of alfalfa for seed production. Chalkbrood, a disease caused by the fungus Ascosphaera aggregata Skou, is seriously threatening the leafcutter bee industry. The disease was first reported in leafcutter bees from Lovelock, Nevada in 1973 and has rapidly spread and become most severe in the western
United States where losses of $>65 \%$ of bees have been reported (Kish et al, 1979; Stephen et al, 1981). Chalkbrood was first detected in Canada in 1982 in Manitoba (Richards, 1985). Since then it has been found as far west as Alberta, where its incidence has increased each year (Goettel, 1990).

Leafcutter bee larvae become infected after consuming pollen and nectar provisions contaminated with $A$ aggregata spores (Vandenberg and Stephen, 1982, 1983; McManus and Youssef, 1984). The

\footnotetext{
* Contribution No 3879033 of the Lethbridge Research Station
} 
spores germinate in the midgut and penetrate into the hemocoel. Larvae soon turn a pink or greyish color and die. Immediately after death, the fungus produces ascospores in spore balls borne within ascomata beneath the host cuticle. The disease is spread through the use of contaminated nesting materials and by adults that have emerged from chalkbrood-infested material (Vandenberg et al, 1980).

Present control practices rely almost exclusively on the decontamination of nesting materials and bee cells using sodium or calcium hypochlorite (Mayer et al, 1988). Heat is also sometimes used to decontaminate nesting materials (Kish et al, 1979; Stephen, 1982). Although these practices have provided some control, they have not stemmed the spread and increase in levels of the disease. This is most probably due to the reintroduction of spores from infested feral bee populations (Stephen, 1982). Consequently, a possible solution would be to use a fungicide as a prophylactic by incorporation into cell provisions.

Several laboratory and field studies have evaluated fungicides incorporated into the leafcutter bee larval food provisions for chalkbrood control (Parker, 1984, 1985; Youssef and McManus, 1985; Fichter and Stephen, 1987; Parker, 1987, 1988; Youssef and Brindley, 1989). However, at times these studies have provided inconsistent and even contradictory results and no fungicides have been registered for control of chalkbrood in leafcutter bees. There is presently a need to develop bioassay methods to identify and test candidate fungicides that are nontoxic to bee larvae, reduce the incidence of chalkbrood and do not detrimentally affect bee behavior and development.

In the present study we bioassayed 5 fungicides by incorporating them into the natural provisions of leafcutter bee larvae.
The effects of these fungicides on growth, mortality and chalkbrood incidence are presented. None of the fungicides reduced mortality at the doses tested; one fungicide actually increased chalkbrood incidence.

\section{MATERIALS AND METHODS}

\section{$M$ rotundata eggs}

Eggs were obtained from a field population of leafcutter bees in an irrigated alfalfa field at the Lethbridge Research Station. The bees were nesting in hives constructed of laminated pine wood nesting material (Richards, 1984). The wood laminates were opened in the field and cells removed. Circular leaf pieces used to cap the cells were carefully removed using a scalpel and the opened cells were examined for the presence of an egg. Cells with eggs were individually placed in 96-well microtiter plates and brought to the laboratory.

\section{A aggregata spore inoculum}

Leafcutter bee cells from a 1988 population of bees near Tilley, Alberta with a $26 \%$ incidence of chalkbrood were supplied by the Canadian Leafcutter Bee Cocoon Testing Centre, Brooks, Alberta. Cadavers were removed from the cells and spores were scraped from those showing typical chalkbrood symptoms. The spores were then passed through a fine plastic screen to remove cuticle debris and kept sealed in a test tube at $4{ }^{\circ} \mathrm{C}$ until needed. Spore viability was determined by placing $\approx 1 \times 10^{6}$ spores into $0.1 \mathrm{ml}$ Sabouraud dextrose broth with $2 \%$ yeast extract, streptomycin $\left(50 \mu \mathrm{g} \cdot \mathrm{ml}^{-1}\right)$ and penicillin $\left(25 \mathrm{IU} \cdot \mathrm{ml}^{-1}\right)$ in a $16-\mathrm{ml}$ capacity sterile test tube. The tube was then filled with $\mathrm{CO}_{2}$ from a pressurized gas cylinder, sealed and incubated at $30^{\circ} \mathrm{C}$ for $24 \mathrm{~h}$. Germination rates were determined by counting numbers of germinated and non-germinated spores. Using this method, we consistently obtained germination rates of $>$ $90 \%$ from this spore batch.

Spore inoculum was prepared immediately prior to use. Spores were placed into a buffered 
isotonic saline solution (BISS) (Earle, 1944). Spore counts were determined using an improved Neubauer hemocytometer and diluted to a final concentration of $1 \times 10^{6}$ spores per $2 \mu \mathrm{l}$.

\section{Fungicides}

The fungicides used were Benlate 50 WP (benomyl, El duPont), Rovral 50 WP (iprodione, Rhone Poulenc), Ascocidin ( $N$-glycosylpolifungin, Warsaw Biotechnical Research and Development Centre), DFMO ( $\alpha-\mathrm{DL}-$ difluoromethylornithine, Merrel-Dow) and a $20 \%$ solution of enilconazole (Janssen Pharmaceutica). Enilconazole was diluted in $70 \%$ ethanol; the other fungicides were diluted in sterile distilled water.

The mean weight of provisions was determined to be $124 \pm 39.3 \mathrm{mg}(\bar{x} \pm S E ; n=10)$. Appropriate serial dilutions of fungicide were prepared so that a $2-\mu l$ aliquot would provide enough fungicide to obtain final concentrations of $1,10,100$ and $1000 \mathrm{ppm}$ in $124 \mathrm{mg}$ of provision.

\section{Bioassay}

Cells were treated with fungicide on the day of collection by injecting $2 \mu$ of the fungicide $\mathrm{di}$ rectly beneath the surface of the provision on the side of the egg using a micropipette. Fifty cells were treated with each fungicide/dose combination. Controls consisted of treatment with either $2 \mu \mathrm{l}$ of water, $70 \%$ alcohol or no treatment. Seventy-five cells were kept in groups of 25 per 96-well microtitration plate. Water was added daily to several empty wells per plate to provide humidity and the plates were covered during incubation.

After incubation at $30^{\circ} \mathrm{C}$ for $24 \mathrm{~h}$ in continuous light, half of the cells in each treatment received $1 \times 10^{6}$ spores of $A$ aggregata in BISS by injecting $2 \mu \mathrm{l}$ of the spores solution on the opposite side of the egg to where the fungicide was injected the previous day. The other half of the treatments received BISS with no spores. At this time many of the eggs had eclosed. The cells were incubated at $30^{\circ} \mathrm{C}$ under continuous light and were examined daily. Records were kept of instar attained at time of death using head capsule widths according to Whitfield et al (1987), time of first defecation, and completion of cocoon, ie, cessation of spinning of cocoon. Eggs not eclosing within $72 \mathrm{~h}$ were considered dead and were removed from the experiment. Four weeks after the last larva had spun its cocoon and entered the prepupal stage, all prepupae were stored at $4^{\circ} \mathrm{C}$. Within 3 weeks of placement at $4^{\circ} \mathrm{C}$, all cells were cut open with a scalpel and the prepupae and cadavers weighed. This entire experiment was repeated 4 times during the summer of 1989: 19, 25, 31 July and 14 August.

\section{Statistical analyses}

Weighted analyses of variance (ANOVA) followed by contrasts to compare treatments with their controls were performed on untransformed, arcsine, and logistic transformed percent mortality data. Weighted analysis was necessary because the damaged and dead eggs were not considered in computing the mortality rates. The weights used for each of the transformations were those suggested by Snedecor and Cochran (1980). As the results were similar no matter which transformation was used, a Bartlett's test (Steel and Torrie, 1980) was performed on the untransformed data. It revealed that variances were homogeneous $\left(\chi^{2}=55.012\right.$; $d f=45 ; P=0.15$ ). Therefore, only the results of statistical analyses of untransformed mortality data are presented. Analyses of variance and contrasts were also performed on untransformed developmental parameters. Levels of significance are denoted as ** for $P<0.01$ and * for $P<0.05$. Means are followed by \pm standard error of the mean. All analyses were carried out using the SAS software (SAS Institute Inc, 1985).

\section{Mortality types}

Dead insects were placed into 4 categories, as listed below.

\section{Sporulating chalkbrood}

These cadavers exhibited the typical chalkbrood symptoms: larvae turned a dull grey or pink col- 
or prior to death. Subsequently, they became chalk-white and mycelia were observed under the cuticle. Within $24 \mathrm{~h}$, ascomata developed beneath the cuticle. As the ascomata developed and darkened, the cadaver took on a marblelike appearance. Ulitimately the cadaver turned a dull black at which time a layer of ascomata could easily be distinguished directly beneath the cuticle. These larvae correspond to Category 1 recently described by Skou and Holm (1989).

\section{Part-sporulating chalkbrood}

These larvae died with the identical symptoms described above except that ascomata only partially covered the cadaver. These correspond to Skou and Holm's Category 2 (Skou and Holm, 1989).

\section{Non-sporulating chalkbrood}

These larvae developed similar symptoms to those described above except that ascomata never developed. Consequently, the larva turned a dull brown color and was hard to the touch. A layer of mycelia could be found beneath the cuticle. These correspond to Skou and Holm's Category 3 (Skou and Holm, 1989).

\section{Non-chalkbrood mortality}

These larvae exhibited several types of symptoms; some turned a shiny black or brown and had a soft greasy or cheesy consistency. Others shriveled upon death and turned a dull brown. Some larvae died during the first 2 instars. Their bodies collapsed at death, which made diagnosis difficult.

\section{RESULTS}

\section{Controls}

Larval mortality rates for the 3 types of control groups are summarized in table I. The addition of either alcohol or water did not significantly affect mortality rates for either challenged or non-challenged groups

Table I. Percent mortality of Megachile rotundata larvae used as controlsa.

\begin{tabular}{|c|c|c|c|c|c|c|}
\hline \multirow[t]{2}{*}{ Diagnosis } & \multicolumn{3}{|c|}{ Challenged $b$} & \multicolumn{3}{|c|}{ Not challenged } \\
\hline & BISS C & + Water $d$ & + Ethanol $\theta$ & BISS & +Water & +Ethanol \\
\hline \multicolumn{7}{|l|}{ Chalkbrood } \\
\hline Sporulating & $34 \pm 8.4$ & $26 \pm 11.7$ & $28 \pm 8.1$ & 0 & $1 \pm 1.2$ & $1 \pm 1.6$ \\
\hline Part-sporulating & $3 \pm 1.1$ & $3 \pm 1.9$ & $1 \pm 1.1$ & $1 \pm 1.1$ & 0 & $1 \pm 1.0$ \\
\hline Non-sporulating & $6 \pm 1.2$ & $9 \pm 1.9$ & $7 \pm 4.3$ & $2 \pm 2.2$ & $5 \pm 1.9$ & $3 \pm 1.7$ \\
\hline Total & $43 \pm 7.1$ & $38 \pm 6.5$ & $36 \pm 6.5$ & $3 \pm 2.1$ & $6 \pm 3.0$ & $6 \pm 2.6$ \\
\hline Non-chalkbrood & $8 \pm 2.8$ & $9 \pm 1.9$ & $17 \pm 4.8$ & $7 \pm 2.7$ & $10 \pm 3.6$ & $10 \pm 2.2$ \\
\hline Total & $51 \pm 5.9$ & $47 \pm 10.4$ & $53 \pm 9.3$ & $10 \pm 2.1$ & $16 \pm 5.8$ & $16 \pm 2.8$ \\
\hline
\end{tabular}

a Values are means \pm SE of 4 replicates each consisting of 25 field-collected eggs reared at $30^{\circ} \mathrm{C}$ each in their own cell and provisions. ${ }^{b}$ Challenged with $1 \times 10^{6}$ ascospores of Ascosphaera aggregata in $2 \mu$ buffered isotonic salt solution (BISS) per cell $24 \mathrm{~h}$ after field collection. cTreated with $2 \mu$ BISS per cell $24 \mathrm{~h}$ after field collection. $d$ Treated with $2 \mu \mathrm{l}$ sterile distilled water per cell on day of collection followed by $2 \mu \mathrm{l}$ BISS for $24 \mathrm{~h}$ thereafter. ${ }^{\bullet}$ Treated with 2 $\mu \mathrm{l} 70 \%$ ethanol per cell on day of collection followed by $2 \mu \mathrm{l}$ BISS for $24 \mathrm{~h}$ thereafter. 
of larvae $(P \geq 0.52$ for all combinations within each treatment category, challenged or non-challenged). Therefore the diluent effect on the food source by the addition of water or alcohol was not significant. Addition of spore inoculum increased mortality $(P \leq 0.01)$ compared with nonchallenged larvae; however, levels of chalkbrood remained $<50 \%$. Chalkbrood evels in non-challenged larvae generally remained $<6 \%$.

Larval developmental parameters for the 3 types of control groups are summarized in table II. For the most part, the addition of either alcohol or water did not significantly affect these parameters. Mean time to death for chalkbrood-infected larvae was between 8-9 days and this oc-

Table II. Growth parameters of Megachile rotundata larvae used as controls a .

\begin{tabular}{|c|c|c|c|c|c|c|c|c|c|}
\hline \multirow[t]{2}{*}{ Parameter } & \multicolumn{4}{|c|}{ BISSc $^{\text {Challenged }^{b}}{ }^{\text {WWater }^{d}}$} & \multirow{2}{*}{\multicolumn{2}{|c|}{+ Ethanole }} & \multicolumn{3}{|c|}{ Not challenged } \\
\hline & & ISSc & & ater d & & & BISS & + Water & + Ethanol \\
\hline \multicolumn{10}{|c|}{$\%$ Defecated } \\
\hline $\begin{array}{l}\text { Chalkbrood } \\
\text { Non-chalkbrood }\end{array}$ & $\begin{array}{l}100 \\
67 \pm\end{array}$ & 33.3 & $\begin{array}{l}90 \pm \\
58 \pm\end{array}$ & $\begin{array}{l}10 \\
14.4\end{array}$ & $\begin{array}{l}100 \\
37 \pm\end{array}$ & & $\begin{array}{l}100 \\
44 \pm 29.4\end{array}$ & $\begin{array}{l}100 \\
50 \pm 28.9\end{array}$ & $\begin{array}{l}100 \\
33 \pm 23.6\end{array}$ \\
\hline \multicolumn{10}{|c|}{$\%$ Completed cocoon } \\
\hline $\begin{array}{l}\text { Chalkbrood } \\
\text { Non-chalkbrood }\end{array}$ & $\begin{array}{l}34 \pm \\
33 \pm\end{array}$ & $\begin{array}{r}9.6 \\
33.3\end{array}$ & $\begin{array}{l}39 \pm \\
12 \pm\end{array}$ & $\begin{array}{l}15.3 \\
12.5\end{array}$ & $\begin{array}{l}45 \pm \\
25 \pm\end{array}$ & $\begin{array}{l}12.7 \\
14.4\end{array}$ & $\begin{array}{l}50 \pm 50.0 \\
0\end{array}$ & $\begin{array}{l}78 \pm 22.2 \\
37 \pm 23.9^{*}\end{array}$ & $\begin{array}{l}50 \pm 28.9 \\
25 \pm 25.0\end{array}$ \\
\hline \multicolumn{10}{|c|}{ Mean days to defecation } \\
\hline $\begin{array}{l}\text { Live } \\
\text { Dead }\end{array}$ & $\begin{array}{l}5,4 \pm \\
5.2 \pm\end{array}$ & $\begin{array}{l} \pm 0.37 \\
\pm 0.28\end{array}$ & $\begin{array}{l}5.5 \\
5.8\end{array}$ & $\begin{array}{l} \pm 0.61 \\
\pm 0.32^{* *}\end{array}$ & $\begin{array}{l}5.6= \\
5.6=\end{array}$ & $\begin{array}{l} \pm 0.56 \\
\pm 0.54\end{array}$ & $\begin{array}{l}5.6 \pm 0.37 \\
5.6 \pm 0.29\end{array}$ & $\begin{array}{l}5.6 \pm 0.34 \\
5.5 \pm 0.48\end{array}$ & $\begin{array}{l}5.7 \pm 0.51 \\
6.1 \pm 0.48\end{array}$ \\
\hline \multicolumn{10}{|c|}{ Mean days to cocoon completion } \\
\hline $\begin{array}{l}\text { Live } \\
\text { Dead }\end{array}$ & $\begin{array}{l}10.0= \\
10.8\end{array}$ & $\begin{array}{l} \pm 0.65 \\
\pm 0.96\end{array}$ & $\begin{array}{l}10.8 \\
10.8\end{array}$ & $\begin{array}{l} \pm 0.32 \\
\pm 1.08\end{array}$ & $\begin{array}{l}10.9= \\
11.8=\end{array}$ & $\begin{array}{l}+0.56 \\
\pm 1.04\end{array}$ & $\begin{array}{l}10.7 \pm 0.78 \\
13.0\end{array}$ & $\begin{array}{l}10.8 \pm 0.80 \\
10.4 \pm 1.15\end{array}$ & $\begin{array}{l}11.2 \pm 0.96 \\
11.7 \pm 0.88\end{array}$ \\
\hline \multicolumn{10}{|c|}{ Mean days to death } \\
\hline $\begin{array}{l}\text { Chalkbrood } \\
\text { Non-chalkbrood }\end{array}$ & $\begin{array}{l}9.1= \\
9.7=\end{array}$ & $\begin{array}{l} \pm 0.28 \\
\pm 1.75\end{array}$ & $\begin{array}{l}8.4 \\
7.1\end{array}$ & $\begin{array}{l} \pm 0.57 \\
\pm 0.83\end{array}$ & $\begin{array}{l}8.3 \pm \\
6.5 \pm\end{array}$ & $\begin{array}{l}0.50 \\
+0.29\end{array}$ & $\begin{array}{l}14.0 \\
12.1 \pm 3.47\end{array}$ & $\begin{array}{l}11.5 \\
9.0 \pm 2.52^{*}\end{array}$ & $\begin{array}{r}13.5 \pm 0.50 \\
9.3 \pm 1.59\end{array}$ \\
\hline \multicolumn{10}{|c|}{ Mean weight (mg) } \\
\hline $\begin{array}{l}\text { Live prepupae } \\
\text { Chalkbrood cada }\end{array}$ & $\begin{array}{l}36 \pm \\
\text { avers }\end{array}$ & 2.6 & $38 \pm$ & 4.2 & $39 \pm$ & 2.9 & $38 \pm 4.9$ & $37 \pm 4.7$ & $38 \pm 4.6$ \\
\hline $\begin{array}{l}\text { Sporulating } \\
\text { Non-sporulating }\end{array}$ & $\begin{array}{l}13 \pm \\
15 \pm\end{array}$ & $\begin{array}{l}1.5 \\
1.5\end{array}$ & $\begin{array}{l}12 \pm \\
13 \pm\end{array}$ & $\begin{array}{l}1.7 \\
1.8\end{array}$ & $\begin{array}{l}14 \pm \\
21 \pm\end{array}$ & $\begin{array}{l}2.1 \\
0.4\end{array}$ & $11^{-}$ & $\begin{array}{l}18 \\
15 \pm 4.9\end{array}$ & $\stackrel{16}{7 \pm 3.9}$ \\
\hline
\end{tabular}

a Values are means \pm SE of 4 replicates each consisting of 25 field-collected eggs reared at $30^{\circ} \mathrm{C}$ each in their own cell and provisions. ${ }^{b}$ Challenged with $1 \times 10^{6}$ ascospores of Ascosphaera aggregata in $2 \mu$ buffered isotonic salt solution (BISS) per cell $24 \mathrm{~h}$ after field collection. c Treated with $2 \mu \mathrm{I}$ BISS per cell $24 \mathrm{~h}$ after field collection. d Treated with $2 \mu$ sterile distilled water per cell on day of collection followed by $2 \mu$ l BISS for $24 \mathrm{~h}$ thereafter. ${ }^{\theta}$ Treated with $2 \mu \mathrm{l} 70 \%$ ethanol per cell on day of collection followed by $2 \mu \mathrm{l}$ BISS for $24 \mathrm{~h}$ thereafter. * Difference from BISS, $P \leq 0.05$. " Difference from BISS, $P \leq 0.01$. 
urred after larvae had excreted and generally before larvae completed their cocoon. Chalkbrood cadaver weight was approximately a third of that of live non-infected prepupae.

\section{Fungicide effects on non-challenged larvae}

Fungicide effects on non-chalkbrood mortality of no-challenged larvae are summarized in figure 1a. All fungicides tested had no significant effect, compared with con- trols, at doses $\leq 100 \mathrm{ppm}$. At $1000 \mathrm{ppm}$, increased mortality occurred in the Ascocidin, Rovral and enilconazole treatments. Similar results were obtained when chalkbrood was included in the mortality, ie total mortality, except that there was no significant effect for Ascocidin at $1000 \mathrm{ppm}(\bar{x}=$ $39 \pm 0.13 \% ; P=0.27$ ) (data not presented).

Fungicide treatments resulted in significant differences compared with the controls (table II) only in the following growth parameters. Rovral at $1000 \mathrm{ppm}$ slightly prolonged developmental time $(\bar{x}=6.0 \pm$
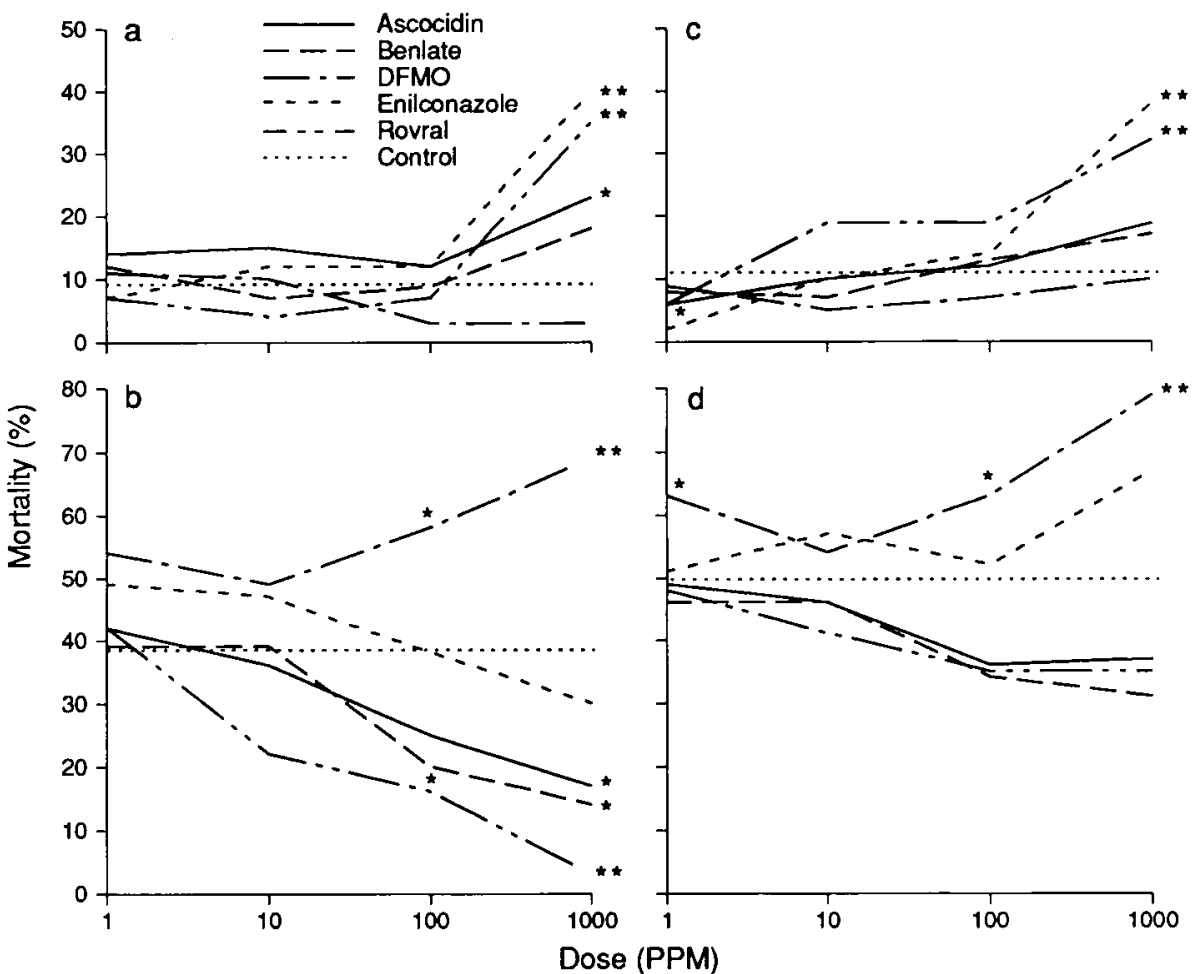

Fig 1. Effects of fungicide treatments on mortality of Megachile rotundata larvae reared individually in their own cell and provisions at $30^{\circ} \mathrm{C}$. Means based on 4 replicates each consisting of 25 fieldcollected eggs at each fungicide concentration. Statistics based on ANOVA comparing mortalities between treatments and controls ( $\left.P \leq 0.05 ;^{* *} P \leq 0.01\right)$. Challenged larvae were inoculated with $1 x$ $10^{6}$ ascospores of Ascosphaera aggregata. a), Non-chalkbrood mortality of non-challenged larvae (controls). b) Chalkbrood mortality of challenged larvae. c) Non-chalkbrood mortality of challenged larvae. d), Total mortality of challenged larvae. 
0.39 days ${ }^{* \star}$ to defecation; $\bar{x}=12.6 \pm 0.79$ days ${ }^{* \star}$ to cocoon completion) and increased non-chalkbrood mortality prior to defecation and completion of cocoon (only $4.2 \pm 4.17 \%$ * mortality occurred after defecation and completion of cocoon). All nonchalkbrood mortality for Ascocidin and Benlate at $1000 \mathrm{ppm}$ occurred before larvae completed their cocoon $(P \leq 0.05)$. Treatment with enilconazole at $1000 \mathrm{ppm}$ resulted in a slight decrease in live prepupal weight $\left(\bar{x}=33 \pm 4.33 \mathrm{mg}^{* \star}\right)$.

\section{Fungicide effects on challenged larvae}

Effects of fungicide treatments on incidence of chalkbrood are summarized in figure $1 \mathrm{~b}$. Rovral at $100 \mathrm{ppm}$ reduced the level of the disease, and this effect was more pronounced at $1000 \mathrm{ppm}$. Ascocidin and Benlate showed an effect only at the highest concentration. Enilconazole was the only fungicide that did not significantly affect chalkbrood incidence at the concentrations tested. DFMO at 100 and 1000 ppm increased the levels of chalkbrood. The results for sporulating chalkbrood mortality were virtually the same as for total chalkbrood (data not presented). Fungicide treatments had no significant effect on the number of larvae dying because of part-sporulating and non-sporulating chalkbrood mortality (data not presented).

Non-chalkbrood mortality increased only at $1000 \mathrm{ppm}$ for Rovral and enilconazole treatments, indicating that the fungicides were toxic at these concentrations (fig 1c). Ascocidin, Benlate and DFMO did not elicit such a toxic effect.

The benefits of Rovral, Benlate and Ascocidin in controlling chalkbrood were negated by the toxicity of these compounds at the higher concentrations. Consequently these compounds had no significant effect on total mortality (fig 1d).
Fungicide treatments had significant effects compared with the controls (table II) on the following growth parameters. The proportion of chalkbrood-infected larvae that died after defecation decreased with Benlate at $1000 \mathrm{ppm}\left(\bar{x}=77 \pm 13.1 \%{ }^{*}\right)$ and with enilconazole at $100(x=90 \pm$ $\left.4.0 \%{ }^{*}\right)$ and $1000 \mathrm{ppm}\left(\bar{x}=84 \pm 11.8 \%{ }^{*}\right)$. Enilconazole at $1 \mathrm{ppm}$ resulted in a decrease in the proportion of chalkbroodinfected larvae that died after cocoon completion $\left(\bar{x}=14.6 \pm 6.57 \%^{* \star}\right)$. In contrast, Ascocidin and Rovral at $100 \mathrm{ppm}$ resulted in a large increase in the proportion of chalkbrood-infected larvae that died after cocoon completion $(\bar{x}=60.8 \pm 3.94 \%$ * and $\bar{x}=60.4 \pm 9.24 \%$ " for Ascocidin and Rovral, respectively).

Mean developmental times for dying larvae as measured by time to defecation were increased with Rovral at $1000 \mathrm{ppm}$ $\left(\bar{x}=7.2 \pm 0.48\right.$ days $\left.{ }^{*}\right)$. Developmental times for dying larvae as measured by the amount of time to cocoon completion were increased for the following treatments: Ascocidin at $100 \mathrm{ppm}(\bar{x}=12.0 \pm 0.93$ days $\left.{ }^{*}\right)$, Benlate at $100(\bar{x}=11.8 \pm 12.29$ days $\left.{ }^{*}\right)$ and $1000 \mathrm{ppm}(\bar{x}=13.0 \pm 0.75$ days $\left.{ }^{\star \star}\right)$ and Rovral at $100(\bar{x}=12.4 \pm 0.48$ days $\left.{ }^{* \star}\right)$ and 1000 ppm $(\bar{x}=16.0 \pm 1.00$ days $\left.{ }^{\star *}\right)$. In contrast, time to cocoon completion was decreased for DFMO at 100 $\left(\bar{x}=7.9 \pm 0.45\right.$ days $\left.{ }^{* *}\right)$ and $1000 \mathrm{ppm}$ $\left(\bar{x}=8.7 \pm 0.31\right.$ days $\left.^{*}\right)$.

The time to death for larvae succumbing to chalkbrood was significantly longer compared with controls (table II) in the following treatments: Ascocidin at 100 $\left(\bar{x}=11.2 \pm 0.59\right.$ days $\left.^{* \star}\right)$ and $1000 \mathrm{ppm}$ $\left(\bar{x}=12.5 \pm 0.60\right.$ days $\left.{ }^{*}\right)$, Benlate at 100 $\left(\bar{x}=11.8 \pm 0.99\right.$ days $\left.{ }^{*}\right)$ and $1000 \mathrm{ppm}$ $\left(\bar{x}=12.3 \pm 0.88\right.$ days $\left.{ }^{* \star}\right)$ and Rovral at 10 $\left(\bar{x}=10.8 \pm 0.77\right.$ days $\left.{ }^{*}\right)$ and $100 \mathrm{ppm}$ $\left(\bar{x}=11.6 \pm 1.7\right.$ days $\left.{ }^{*}\right)$. There were no significant differences in the number of days to death for non-chalkbrood mortality. 
The mean weights sporulating cadavers were higher than for controls (table II) in the following treatments: Ascocidin at $1 \mathrm{ppm}\left(\bar{x}=15 \pm 3.6 \mathrm{mg}{ }^{* *}\right)$. Benlate at 100 ppm $\left(\bar{x}=17 \pm 3.3 \mathrm{mg}{ }^{*}\right)$. DFMO at $1 \mathrm{ppm}$ $(\bar{x}=15 \pm 3.2 \mathrm{mg} *), 10 \mathrm{ppm}(\bar{x}=15 \pm 3.6$ $\left.\mathrm{mg}^{*}\right)$ and $100 \mathrm{ppm}\left(\bar{x}=17 \pm 1.7 \mathrm{mg}{ }^{*}\right)$ and Rovral at $10 \mathrm{ppm}\left(\bar{x}=19 \pm 1.4 \mathrm{mg}{ }^{* *}\right), 100$ ppm $\left(\bar{x}=19 \pm 3.6 \mathrm{mg}^{* *}\right)$ and $1000 \mathrm{ppm}$ $\left(\bar{x}=32 \pm 0 \mathrm{mg}{ }^{*}\right)$. The mean weight for non-sporulating cadavers was only slightly lower for enilconazole at $1000 \mathrm{ppm}(\bar{x}=9$ $\left.\pm 1.7 \mathrm{mg}{ }^{\star}\right)$. The mean weight for live prepupae was slightly lower for Ascocidin at $1000 \mathrm{ppm}\left(\bar{x}=34 \pm 0.3 \mathrm{mg}{ }^{\star}\right)$.

\section{Comparisons between challenged and non-challenged larvae}

Comparisons between mortalities of challenged and non-challenged control groups revealed that total mortalities were higher $(P<0.01)$ for the challenged groups (table 1). However, there were no significant differences in the rates of non-chalkbrood mortality between these groups. Similarly, there were no significant differences in the different growth parameters measured (table II).

Comparisons were also made between challenged and non-challenged groups at the highest fungicide treatments. Challenged larvae receiving DFMO and enilconazole had significantly higher total mortalities (fig 1d) than non-challenged larvae $(\bar{x}=11 \pm 2.8 \%$ ** and $\bar{x}=41 \pm 12.0 \%$ ** mortality for non-challenged larvae treated with DFMO and enilconazole respectively). There were no significant differences between challenged and non-challenged larvae receiving the highest dose treatments for non-chalkbrood mortality nor for any growth parameters monitored.

\section{DISCUSSION AND CONCLUSION}

Previous bioassays were performed using fungicides incorporated in artificial diets (Youssef and McManus, 1985; Fichter and Stephen, 1987; Youssef and Brindley, 1989). Using artificial diets allows the fungicide and spore inoculum to be uniformily incorporated into the diet. However, the nutritional quality of natural provisions and presence of associated microflora may influence larval susceptibility to chalkbrood and the fungicidal activity of fungicides being tested. A bioassay using artificial diet performed with the spore inoculum used in the present study resulted in a 5000 -fold decrease in $L_{50}$ compared with the results obtained here (Vandenberg, personal communication). Further comparisons between artificial and natural diet-fed larvae and their susceptibility to chalkbrood are in progress.

In the present study, larvae were reared in their own leaf cell and on their own natural provisions. Although neither fungicide nor spores were uniformly distributed in the provision, the variability in the data was much lower than for those obtained by Fichter and Stephen (1987) using artificial diets.

The addition of either $2 \mu$ of alcohol or water did not significantly affect mortality or susceptibility to chalkbrood (table I). Background levels of chalkbrood in nonchallenged larvae were under $10 \%$. Since the disease is not known to occur in the field population from which the eggs were obtained and has not been detected in the subsequent season, this background level may have been due to laboratory contamination and possible increased susceptibility through laboratory manipulation and rearing conditions. Addition of $1 \times 10^{6}$ ascospores/cell resulted in $36-43 \%$ inci- 
dence of chalkbrood. These results are similar to those obtained by Fichter and Stephen (1987) but contrast sharply with those of Youssef and McManus (1985) and Youssef and Brindley (1989), who were able to induce $68-100 \%$ chalkbrood through the addition of $1 \times 10^{5}$ ascospores per bee. These discrepancies may be due to the differences in background levels of chalkbrood in field populations from which larvae were obtained, batches of spores used, and diets used.

Death due to chalkbrood occurred in 89 days, after larvae had defecated and generally before larvae had fully spun a cocoon (table II). This is in agreement with results of Stephen et al (1981) and corresponds to the 4th instar (Whitfield et al, 1987) at which time the mid and hind guts join and defecation begins (Stephen et al, 1981). This supports the observations of McManus (1982; as cited by Youssef et al, 1984) that " $A$ aggregata... seldom induce any disease symptoms prior to the larvae becoming mature". Stephen et al (1981), however, noted that "the fungus failed to sporulate in any larvae inoculated during the first instar". In contrast, in the present study, all larvae were challenged during the first instar and the majority of those succumbing to chalkbrood resulted in sporulating cadavers (table I).

Although Ascocidin, Benlate and Rovral significantly reduced the incidence of chalkbrood (fig 1b), none of these significantly reduced overall mortality at the concentrations tested, because these fungicides proved toxic to the larvae at 1000 ppm (figs 1a, c). Only Benlate at 1000 $\mathrm{ppm}$ significantly reduced incidence of chalkbrood (fig 1b), proved non-toxic to larvae (figs 1a, c) and did not affect developmental rates; however, overall mortality was not significantly reduced (fig 1d). These results substantiate those of Fichter and Stephen (1987), who also found that
Benlate was marginally effective at 1000 ppm. These researchers further demonstrated that Benlate was effective at $10000 \mathrm{ppm}$. Even at $100000 \mathrm{ppm}$, it was only slightly detrimental to bee larvae, which demonstrated a wide safety spectrum. However, as Benlate is available as a $50 \%$ wettable powder, an effective control program would require the introduction of Benlate into each cell equivalent to $2 \%$ of the weight of its provisions. This probably would be difficult to administer and explains why this fungicide was only marginally effective in field trials (Parker, 1987).

Rovral demonstrated the greatest activity against chalkbrood, exhibiting fungicidal effects at 100 and $1000 \mathrm{ppm}$ (fig 1b). However, because of its toxic effects at $1000 \mathrm{ppm}$ (figs 1a, c), overall mortality was not reduced (fig 1d). Since Rovral exhibited some control of chalkbrood and had no toxic effects to larvae at $100 \mathrm{ppm}$, it is possible that this fungicide may be efficacious against chalkbrood and exhibit little toxic effect against larvae between the doses of 100 and $1000 \mathrm{ppm}$. This narrow dose range may prove to be difficult to administer under field conditions.

Rovral was the only fungicide to increase mortality prior to larval defecation and to prolong developmental time. Treatment with Rovral at rates as low as 10 ppm increased the length of time to death for larvae succumbing to chalkbrood. Treatment with Rovral at 100 and 1000 ppm also resulted in an increase in the proportion of chalkbrood-infected larvae that died after completion of their cocoon. This indicates that, although the fungicide was unable to completely inhibit the mycosis, it delayed disease progression. The delay in mortality may be responsible for the increased weight of the sporulating chalkbrood cadavers; larvae gained more weight before succumbing to the disease. 
The increased weight of sporulating cadavers may translate to increased spore load as demonstrated by Vandenberg et al (1980) for non-fungicide treated larvae. Using the linear relationship between host weight and spore load (Vandenberg et al, 1980 ), it is estimated that a sporulating cadaver from the Rovral treatments $(19 \mathrm{mg})$ would produce $47 \%$ more spores compared with controls. Such an increase in spore load could negate the benefits obtained in the reduction of chalkbrood incidence. Since the phenomenon of weight gain in treated larvae succumbing to chalkbrood also has been demonstrated, although to a lesser degree, with Ascocidin, Benlate and DFMO, the possible increase in spore load should be further investigated before any fungicide is registered for chalkbrood control.

Ascocidin, a water soluble $N$-methylglucamine salt of $\mathrm{N}$-glycosylpolifungin (Plociennik et al, 1978), is used in Poland for control of Ascosphaera apis (Maassen ex Claussen) Olive and Spiltoir in honey bees at a rate of $200 \mathrm{mg}$ per hive (A Hartwig, Warsaw Agricultural University, personal communication). In the present study, Ascocidin at $1000 \mathrm{ppm}$ only marginally reduced chalkbrood incidence in leafcutter bees and proved to be slightly toxic to bee larvae.

Enilconazole, an imidazole derivative, is formulated in alcohol and is being investigated as a promising fumigant for chalkbrood control in honey bees (Janssen Pharmaceutica, unpublished observations). In the present study, enilconazole was added directly to the leafcutter bee provisions dissolved in alcohol. Lack of water solubility of the fungicide may have prevented proper targeting to the fungicide in the in vivo bioassay. Further studies are continuing and enilconazole is being evaluated as a potential fumigant sporicide for decontamination of bee cells and beekeeping equipment.

DFMO was the only fungicide tested that actually increased the levels of chalkbrood (fig 1b). Fichter and Stephen (1987) also demonstrated such a phenomenon with Carbamate and Orthocide (captan) at $100 \mathrm{ppm}$ but not at higher dosages. Interestingly, captan has been the fungicide that has proven most efficacious in field and other laboratory trials (Parker, 1985; Youssef and McManus, 1985; Parker, 1987). Fichter and Stephen (1987) found that Orthocide is toxic to non-challenged larvae and suggested the increase in levels of chalkbrood was due to the compounds acting as stressors. DFMO, a polyamine synthesis inhibitor, has a wide range of antimicrobial activity that includes bacteria (Bitonti and McCann, 1987). Therefore, an alternate hypothesis is that these compounds may inhibit certain microorganisms that act as antagonists to $A$ aggregata. For instance, Gilliam et al (1988) have recently demonstrated that microorganisms present in honey bee hives produce substances inhibitory to $A$ apis. Studies are presently in progress to determine the role of associated microorganisms in chalkbrood pathogenesis. DFMO may prove to be a useful tool in these studies.

In previous field studies it was noted that fungicide treatments increased the proportion of non-sporulating cadavers (Parker, 1984, 1985). Laboratory assays also revealed that the proportion of sporulating $M$ rotundata cadavers decreased with increase in fungicide dose (Fichter and Stephen, 1987). It was suggested that fungicides may inhibit spore formation and thus reduce the inoculum available to a subsequent generation of bees. In the present study, fungicide treatments had no significant effect on the number of larvae 
dying because of non-sporulating chalkbrood. The increased mortalities at higher fungicide doses are attributable to nonchalkbrood mortality. As there were no differences in the incidence of nonchalkbrood mortalities between the challenged and non-challenged control groups, it is likely that non-chalkbrood mortality was properly diagnosed and was not a part of the chalkbrood syndrome.

Although the present study has not identified any new fungicides with exceptional promise as effective control agents of chalkbrood in leafcutter bees, it has provided baseline data on the pathology of chalkbrood and how it relates to the bioassay of fungicides. Present in vitro studies will allow for further evaluation of bioassay methods by relating the fungicidal properties of the compounds tested to the results obtained in vivo. Such information should prove useful in the development of a rapid screening mechanism for potential control agents of chalkbrood.

\section{ACKNOWLEDGMENTS}

We thank $G$ Duke, $T$ Myer and $J$ Virostek for technical assistance; Janssen Pharmaceutica, Dupont, Rhone Poulenc, A Hartwig, Warsaw Agricultural University, and R St Leger, Boyce Thompson Institute, for providing the fungicides; L Kaminski and S Simms of the Canadian Alfalfa Leafcutter Bee Cocoon Testing Centre for providing chalkbrood cadavers; and D Gaudet and $J$ Vandenberg for critically reviewing the manuscript. Partial funding for this study was provided by Janssen Pharmaceutica.

Résumé - Essais de différents fongicides pour le contrôle du couvain plâtré chez la mégachille Megachile rotundata. Des tests biologiques ont été réalisés afin de déterminer les effets de divers fongicides sur différents paramètres du développement des mégachiles et sur l'étendue du couvain plâtré. Des séries de dilution de fongicides ont été préparées de telle façon qu'un aliquot de $2 \mu$ fournisse assez de fongicide pour obtenir une concentration finale de 1, 10, 100 ou $1000 \mathrm{ppm}$ dans $124 \mathrm{mg}$, qui représente le poids moyen des provisions contenues dans une cellule. Des cellules de couvain récoltées dans la nature, et contenant des œufs, ont été traitées avec des fongicides le jour même de leur prélèvement, par un dépôt de $2 \mu l$ de suspension de fongicides directement dans les provisions. Après une incubation à $30^{\circ} \mathrm{C}$ pendant $24 \mathrm{~h}$, la moitié des cellules de chaque groupe traité reçurent $10^{6}$ spores de Ascosphaera aggregata. Les cellules ont été incubées à $30^{\circ} \mathrm{C}$ et ont été examinées quotidiennement. On a relevé le stade de développement au moment de la mort, au moment de la $1^{r e}$ défécation, et à l'achèvement du cocon. Les prénymphes et les cadavres ont été pesés. Les insectes morts ont été répartis en plusieurs catégories : couvain plâtré sporulant, partiellement sporulant et non sporulant, et couvain non plâtré. Les taux de mortalité pour les 3 groupes contrôles sont reportés dans le tableau I. L'addition d'un inoculum de spores augmente le taux de mortalité comparativement aux larves non traitées, mais les niveaux de couvain plâtré restent inférieurs à $50 \%$. Les effets des fongicides sur la mortalité des larves non traitées sont portés dans la figure 1a. À la concentration de 1000 ppm, un accroissement de mortalité apparaît pour les traitements à l'Ascocidin, au Rovral et à l'Enilconazole, ce qui indique que ces composés ont été toxiques pour les larves à ces concentrations. Le Rovral à 1000 ppm a entraîné un temps de développement légèrement prolongé et une augmentation de la mortalité du couvain non plâtré avant la défécation et l'achèvement du cocon. Les effets d'un traitement fongicide sur l'incidence du couvain plâtré sont résumés dans la figure 1b. L'Enilconazole a 
été le seul fongicide qui n'a pas affecté significativement la fréquence du couvain plâtré. Le Rovral a réduit l'incidence du couvain plâtré à 100 et 1000 ppm. À l'inverse, le DFMO à 100 et 1000 ppm augmente le niveau du couvain plâtré. On peut faire l'hypothèse que cela pourrait être dû à l'inhibition de la microflore associée, qui serait antagoniste de $A$ aggregata. Les traitements fongicides n'ont pas eu d'effets significatifs sur le nombre de larves mourantes en raison du couvain plâtré partiellement sporulant ou non sporulant. La mortalité du couvain non plâtré s'est accrue seulement à 1000 ppm pour les traitements au Rovral et à l'Enilconazole, ce qui montre à nouveau que ces fongicides étaient toxiques pour les larves d'abeilles (fig 1c). Les effets de la réduction du niveau de couvain plâtré par le Rovral, le Benlate et l'Ascocidin ont été annulés par la toxicité de ces composés qui est démontrée par les mortalités totales (fig 1d). L'Ascocidin et le Rovral à 100 ppm entraînent une forte augmentation de la proportion de larves infectées par le couvain plâtré, qui meurent après l'achèvement du cocon, comparativement aux contrôles (tableau (I). Les temps de développement moyens pour les larves mortes, obtenus par la mesure du moment de la défécation, s'accroissent avec le Rovral à 1000 ppm. Le traitement à l'Ascocidin, au Benlate, au DFMO et au Rovral a entraîné des sporulations très importantes des cadavres, comparativement aux contrôles. Apparemment, les fongicides ont été incapables d'inhiber complètement la mycose chez ces larves, et ont agi en retardant la progression de la maladie et la mort. On fait l'hypothèse que l'augmentation du temps de survie a abouti à un accroissement du poids du corps, ce qui peut avoir entraîné un accroissement de la masse des spores. Les mortalités du couvain non plâtré, dans les groupes contrôles testés et non testés, n'ont pas été significative- ment différentes, ce qui montre que la mortalité du couvain non plâtré n'était pas reliée à l'addition d'un inoculum de spores, et donc ne faisait pas partie du syndrôme du couvain plâtré. Dans des études précédentes, il a été suggéré que des fongicides pouvaient inhiber la formation de spores par accroissement de la proportion de cadavres non sporulants, réduisant ainsi l'inoculum disponible pour la génération ultérieure d'abeilles. Dans ce travail, il a été démontré que les traitements fongicides n'ont pas d'effets significatifs sur la proportion de larves mourantes à cause du couvain plâtré non sporulant; l'augmentation de mortalité était imputable à la mortalité du couvain non plâtré. Bien que la présente étude n'ait pas permis d'identifier des fongicides promettant un contrôle efficace du couvain plâtré chez les mégachiles, elle apporte néanmoins des données de base sur cette pathologie et sur la façon dont elle interfere avec les tests biologiques des fongicides. Des études in vitro actuellement en cours permettront dans les études ultérieures de relier les propriétés fongicides des composés testés aux résultats obtenus in vivo. De telles informations devraient apporter des renseignements très utiles dans le développement d'une méthode de criblage rapide des moyens de contrôle potentiels du couvain plâtré.

Ascosphaera aggregata / Megachile rotundata / couvain plâtré / lutte chimique / fongicide

\section{Zusammenfassung - Biotest mit ausge- wählten Fungiziden zur Bekämptung der Kalkbrut bei der Luzerne- Blattschneiderbiene Megachile rotunda- ta. Es wurden Biotests zur Bestimmung der Wirkung ausgewählter Fungizide auf verschiedene Entwicklungsmerkmale und das Vorkommen von Kalkbrut bei Megachi- le rotundata ausgeführt. Es wurden geeig-}


nete Reihenverdünnungen der Fungizide hergestellt, so daß ein Anteil von $2 \mu$ l einen Fungizidgehalt von 1, 10, 100 oder $1000 \mathrm{ppm}$ in $124 \mathrm{mg}$ ergeben würde, dem mittleren Gewicht der Nahrungsmenge in einer Zelle. Im Feld gesammelte Zellen mit einem Ei wurden am Tage des Einsammelns behandelt durch Applikation von 2 $\mu l$ der Suspension direkt auf den Nahrungsvorrat. Nach Incubation bei $30^{\circ} \mathrm{C}$ für 24 Stunden erhielt die Hälfte der Zellen jeder Behandlungsgruppe $1 \times 10^{6}$ Sporen von Ascosphaera aggregata. Die Zellen wurden bei $30^{\circ} \mathrm{C}$ inkubiert und täglich kontrolliert. Es wurde das Häutungsstadium zur Zeit des Absterbens, der Zeitpunkt der ersten Defäkation und die Vollendung des Kokons protokolliert. Vorpuppen und Kadaver wurden gewogen. Tote Insekten wurden nach den folgenden Kategorien diagnostiziert: sporulierende, teilsporulierende und nicht-sporulierende Kalkbrut. Die Mortalität bei den drei Kontrollgruppen ist in Tabelle I zusammengefaßt. Die Zugabe der Sporenaufschwemmung erhöhte die Sterblichkeitsrate im Vergleich zu nicht infizierten Larven, aber der Kalkbrutbefall blieb unter $50 \%$. Die Wirkung der. Fungizide auf die Nicht-Kalkbrut-Mortalität bei Abbildung nicht infizierten Larven ist in Abbildung a zusammengefaßt. Bei 1000 ppm war eine erhöhte Mortalität nach Behandlung mit Ascocidin, Rovral und Enilconazole zu beobachten, ein Hinweis, daß diese Verbindungen in dieser Konzentration toxisch wirkten. Rovral bei 1000 ppm bewirkte eine leichte Entwicklungsverzögerung und eine Erhöhung der NichtKalkbrut-Mortalität vor der Defäkation und Beendigung der Verpuppung. Die Wirkungen der Fungizidbehandiungen auf das Auftreten von Kalkbrut sind in Abbildung 1d dargestellt. Obwohl in der gegenwärtigen Untersuchung keine neuen wirkungsvollen Fungizide gefunden wurden, hat sie doch wichtige Aufschlüsse über die Patho- logie der Kalkbrut als Vorbereitung für weitere Prüfungen gebracht.

Megachile rotundata / Kalkbrut / Ascosphaera / Fungizide / chemische Bekämpfung

\section{REFERENCES}

Bitonti AJ, McCann PP (1987) Inhibition of polyamine biosynthesis in microorganisms. In: Inhibition of Polyamine Metabolism (McCann PP, Pegg AE, Sjoerdsma A, eds) Academic Press, NY

Earle WR (1944) Production of malignancy in vitro. IV. The mouse fibroblast changes seen in living cells. J Natl Cancer Inst 4, 165-212

Fichter BL, Stephen WP (1987) Efficacy of selected fungicides against chalkbrood of the leafcutting bee. J Agric Res 26, 137-143

Gilliam M, Taber ST III, Lorenz BJ, Prest DB (1988) Factors affecting development of chalkbrood disease in colonies of honey bees, Apis mellifera, fed pollen contaminated with Ascosphaera apis. J Invertebr Pathol 52, 314-325

Goettel M (1990) Chalkbrood in Canadian leafcutting bees, present status and consideration for the future. In: Proc Canadian Alfalfa Seed School and Trade Show, Calgary, Alberta. Canadian Alfalfa Seed Council 9, 1319

Kish LP, Waters ND, Homan HW (1979) Chalkbrood. Curr Info Ser No 477, Univ Idaho Coop Ext Serv Agric Exp Stn. Moscow, ID

Mayer DF, Lunden JD, Kious CW (1988) Effects of dipping alfalfa leaf-cutting bee nesting materials on chalkbrood disease. Appl Agric Res 3, 167-169

McManus WR (1982) In vivo development of Ascosphaera aggregata Skou in the alfalfa leafcutting bee, Megachile rotundata (Fabricius): a light and electron microscope study. M Sc Thesis, Utah University, Logan, UT

McManus WR, Youssef NN (1984) Life cycle of the chalk brood fungus, Ascosphaera aggregata, in the alfalfa leafcutting bee, Mega- 
chile rotundata, and its associated symptomology. Mycologia 76, 830-842

Parker FD (1984) Effect of fungicide treatments on incidence of chalkbrood disease in nests of the alfalfa leafcutting bee (Hymenoptera: Megachilidae). J Econ Entomol 77, 113-117

Parker FD (1985) Effective fungicide treatment for controlling chalkbrood disease (Ascomycetes: Ascosphaeraceae) of the alfalfa leafcutting bee (Hymenoptera: Megachilidae) in the field. J Econ Entomol 78, 35-40

Parker FD (1987) Further studies on the use of fungicides for control of chalkbrood of the alfalfa leafcutting bee. J Apic Res 26, 144-149

Parker FD (1988) Influence of wood paper, and plastic nesting units on efficacy of three candidate fungicides for control of chalkbrood in the alfalfa leafcutting bee (Hymenoptera: Megachilidae). J Econ Entomol 81, 789-795

Plociennik Z, Kowszyk-Gindifer Z, Horodecka M, Lewczuk-Mrozek Z, Bojarska-Dahlig $\mathrm{H}$ (1978) Synthesis and characteristics of $N$ methylglucamine salts of $\mathrm{N}$-glycosylpolifungin, $\mathrm{N}$-glycosyl mystatin and $\mathrm{N}$ glycosyl-amphotericin B, the water-soluble derivatives of antifungal polyene antibiotics. Acta Pol Pharm 35, 125

Richards KW (1984) Alfalfa leafcutter bee management in Western Canada. In: Publication 1495E. Res Branch, Agric Canada, Ottawa, Canada

Richards KW (1985) Detection of a chalkbrood fungus, Ascosphaera aggregata, in larvae of the alfalfa leafcutter bee (Hymenoptera: Megachilidae) from western Canada. Can Entomol 117, 1143-1145

SAS Institute Inc (1985) SAS User's Guide: Statitics, Version 5. SAS Institute, Cary, NC

Skou JP, Holm (1989) Ascosphaera tenax species nova and a variant of Ascosphaera aggregata. Mycotaxon 35, 211-218

Snedecor GW, Cochran WC (1980) Statistical Methods. Lowa State University Press, Ames, IA, 7th edn
Steel RGD, Torrie JH (1980) Principles and Procedures of Statistics. McGraw Hill, NY, 2nd edn

Stephen WP (1982) Chalkbrood control in the leafcutting bee. Proc Int Symp Alfalfa Leafcutting Bee Management 1 (Rank GH, ed) Univ of Saskatchewan, Saskatoon, Sask, Canada, 98-107

Stephen WP, Vandenberg JD, Fichter BL (1981) Etiology and epizootiology of chalkbrood in the leafcutting bee, Megachile rotundata (Fabricius), with notes on Ascosphaera species. Bull 653, Oregon State Univ Agric Exp Stn, Corvallis, OR

Vandenberg JD, Fichter BL, Stephen WP (1980) Spore load of Ascosphaera species on emerging adults of the alfalfa leafcutting bee, Megachile rotundata. Appl Environ Microbiol $39,650-655$

Vandenberg JD, Stephen WP (1982) Etiology and symptomology of chalkbrood in the alfalfa leafcutting bee, Megachile rotundata. $J$ Invertebr Patho/ 39, 133-137

Vandenberg JD, Stephen WP (1983) Pathogenesis of chalkbrood in the alfalfa leafcutting bee, Megachile rotundata. Apidologie 14, 333-341

Whitfield GH, Richards KW, Kveder TM (1987) Number of instars of larvae of the alfalfa leafcutter bee, Megachile rotundata (F) (Hymenoptera: Megachilidae). Can Entomol 119, 859-865

Youssef NN, Brindley WA (1989) Effectiveness of Botran and DPX 965 as growth inhibitors of Ascosphaera aggregata (Ascosphaeraceae) in the alfalfa leafcutting bee (Hymenoptera: Megachilidae). J Econ Entomol 82, 1335-1338

Youssef NN, McManus WR (1985) Captan: a promising fungicide for management of chalkbrood diseases in the alfalfa leafcutting bee. J Econ Entomol 78, 428-431

Youssef NN, Roush CF, McManus WR (1984) In vivo development and pathogenicity of Ascosphaera proliperda (Ascosphaeraceae) to the alfalfa leafcutting bee, Megachile rotundata. J Invertebr Pathol 43, 11-20 